\title{
Household Labor, Gender Roles, and Family Satisfaction: A Cross- National Comparison
}

\author{
Renata Forste \\ Brigham Young University - Provo, renata_forste@byu.edu \\ Kiira Fox \\ Brigham Young University - Provo
}

Follow this and additional works at: https://scholarsarchive.byu.edu/facpub

Part of the Family, Life Course, and Society Commons, Gender and Sexuality Commons, and the Inequality and Stratification Commons

\section{Original Publication Citation}

Forste, Renata, \& Kiira Fox. 2012. “Household Labor, Gender Roles, and Family Satisfaction: A Cross-National Comparison.”Journal of Comparative Family Studies,43(5):613-631.

\section{BYU ScholarsArchive Citation}

Forste, Renata and Fox, Kiira, "Household Labor, Gender Roles, and Family Satisfaction: A Cross-National Comparison" (2012). Faculty Publications. 3897.

https://scholarsarchive.byu.edu/facpub/3897

This Peer-Reviewed Article is brought to you for free and open access by BYU ScholarsArchive. It has been accepted for inclusion in Faculty Publications by an authorized administrator of BYU ScholarsArchive. For more information, please contact ellen_amatangelo@byu.edu. 


\section{Household Labor, Gender Roles, and Family Satisfaction: A Cross-National Comparison}

Renata Forste

Kiira Fox

\section{INTRODUCTION}

Due to the interrelation of work and family domains recent scholarship has been devoted to determining the impact of women's rising employment on the home (Batalova and Cohen, 2002; Bianchi, Milkie, Robinson, and Sayer, 2000; Doucet, 2006; Lewin-Epstein and Stier, 2006). More specifically, research has focused on what happens to the division of domestic labor in the wake of mother's paid employment and how the new arrangements are determined. In general, women have responded by dedicating less time to housework and men have responded by increasing their participation in unpaid labor (Fox, 2009; Hook, 2006). That said, male contributions do not compensate for the decrease in time by women in the home, and women still maintain responsibility for the majority of household and childcare responsibilities (Allen and Webster, 2001; Batalova and Cohen, 2002; Baxter, 2002; Diefenbach, 2002; Doucet, 2006; Hochschild, 1989; Iversen and Rosenbluth, 2003; Lewin-Epstein and Stier, 2006; Sanchez and Thompson, 1997). The relationship between women and domestic responsibility identified by Hochschild over 20 years ago thus holds true today; gender remains the chief predictor of who performs housework (Baxter, 2002; Hochschild, 1989; Hook, 2006). These gendered divisions of labor and inequality in domestic responsibility also tend to become more pronounced when couples become parents (Fox, 2009).

In addition to women dedicating more time, they also continue to perform traditionally female tasks (Bianchi et al., 2000). In terms of domestic labor, women are generally responsible for daily routine tasks such as cooking and laundry, whereas men are more likely to perform infrequent household maintenance chores (Hochschild, 1989). Regarding childcare, women are more likely to do the planning, worrying, and decision making for their children while men are more apt to spend "childcare" time playing with children (Doucet, 2006, p. 142, 198). While some variance in the gendered division of domestic and childcare duties exists, these general trends are manifest throughout the world (Baxter, 2002; Chen, 2005; Coltrane 2000; Diefenbach, 2002). In fact, studies unanimously point to women's continued responsibility for the bulk of domestic labor, despite men's increased participation, rising female involvement in the labor force, nationality, and level of national development (Batalova and Cohen, 2002; Diefenbach, 2002; Habib, Nuwayhid, and Yeretzian, 2006; Hook, 2006). Given that attitudes in part predict behavior, gender ideology is often used to explain the division of labor in the home (Apparala, Reifman, and Munsch, 2003).

Many individual and national-level influences have been studied to understand why the

'Department of Sociology, 2008C JFSB, Brigham Young University, Provo, UT 84602 U.S.A. 
association between females and housework persists. While much research has been dedicated to answering this question, a definitive answer remains elusive. Although our aim is not to further understanding of why it persists, that it persists serves as the point of departure for our study; our interest is in its association with family satisfaction. The fact remains that despite the international liberalizing of gender ideology, women continue to perform the bulk of work in the home. It follows that the divergence of ideology and the division of labor would yield more instances of incongruence between attitude and behavior. Such incongruence is likely to have implications for the experience and happiness of those involved, but perhaps more for some than for others. We thus ask whether this increased incongruence influences individuals' satisfaction with family life and whether this relationship differs by national context.

In this study we offer an integrated micro and macro-level, political-economy perspective to frame the relationship between ideology, the division of household labor, and family satisfaction. As a combination of individual-level and national-level factors have been found to more comprehensively explain the division of labor, we will briefly review the most relevant theories employed and influences examined along both dimensions. Because little research on the impact of these gendered relationships on family satisfaction has been conducted, we will use information on how such relationships have been found to influence related types of satisfaction to extrapolate to family satisfaction specifically.

\section{BACKGROUND}

\section{Micro-level Theories}

There are essentially four micro-level theories that are used to explain the division of domestic labor: time availability, economic bargaining (resource dependence) and the related socialization perspectives: gender ideology and "doing gender." Time availability is a derivative of equity theory which claims the work input and output of partners will be fair, regardless of whether the contribution is in the form of paid or unpaid labor (Braun, LewinEpstein, Stier, and Baumgartner, 2008). From this perspective, it is 'fair' when spouses that spend more time in market activity spend less time on domestic tasks (Braun et al., 2008). It follows that the partner with more time (less responsibility in the labor force) be held accountable for housework, and as women generally spend comparatively less time in paid employment than their spouse, they perform more work in the home. As a general rule, the gendered division of labor is a response to time shortages and constraints (Fox, 2009).

The second "gender neutral" theory, economic bargaining, posits that women who are more economically dependent on their spouse have less bargaining power in their relationship and are thus more frequently relegated to household duties (see Braun et al., 2008). The spouse with resources tends to have greater control in determining the division of labor between the couple and, as baby care and domestic labor are not highly valued, typically assigns the other responsibility for those tasks (Fox, 2009). As a woman gains economic and human capital in the form of increased education and income, her decision making power increases, yielding more equitable divisions of household labor (Davis and Greenstein, 2004; Lewin-Epstein and Stier, 2006). This relationship is non-linear, however; wives that earn more than their husbands tend to perform more housework as well, possibly to neutralize role deviance (Davis \& Greenstein, 2004; Greenstein, 2000; Fernandez and Sevilla-Sanz, 2006; LewinEpstein and Stier, 2006).

The other two, gender ideology and "doing gender," are gender construction arguments. 
Gender ideologies can be conceptualized as "a set of social beliefs about men's and women's roles and relationships in varied social institutions" (Doucet, 2006, p. 193). They are influenced by cultural norms, feelings about their past, and by how they view their mating opportunity (Hochschild, 1989). Attitudes regarding gender are loosely categorized into three types: traditional, transitional, and egalitarian (Hochschild, 1989). Transitional is something of an ambiguous bridge between belief in very distinct gender roles and work that is not defined as either male or female (Nordenmark and Nyman, 2003). As the exact meanings of these terms vary by context, their explanatory power is limited and interpretation of their effects must be made with care. Attitudes deemed. egalitarian, however, tend to be held by those that are female, young, liberal, of higher social status, and educated. While ideology appears to affect behavior, its influence is in part determined.by which spouse holds a given attitude.

According to Batalova and Cohen (2002), the doing gender. perspective "challenges" the gender neutrality of the first two arguments and the "rigidity" of the third (see Batalova and Cohen, 2002). This theory "focuses on individual's construction of themselves through relational, interactional labors such as housework and childcare" (see Doucet, 2006, p. 35). The crux of this theory is the social reproduction of gender roles, which dictate what the appropriate behaviors and responsibilities for men and women are. The household is thus the heart of gender production (Lewin-Epstien and Stier, 2006) and serves as a forum in which men and women enact these gendered roles. This perspective explains the curvilinear relationship between resource dependence and division of domestic labor; in households with a female breadwinner, the couple will often 'do gender' to lessen their sense of norm violation. Accordingly, the woman will perform more housework and the man less. In this way, responsibility is seen as a relationship both between an individual and a given task, as well as one between people (Doucet, 2006).

Finally, demographic and household characteristics of individuals are also associated with how labor is divided. Education, income, occupation, and socioeconomic status tend to have a positive relationship with less traditional divisions of labor. While men's attitudes do not vary drastically across class, social status is positively related to female egalitarian ideologies and resources, resulting in more equal sharing of domestic responsibilities (Apparala et al., 2003). Being middle class is also associated with increased social resources in the form of support from family and friends, as well as social skills that help new parents handle childcare responsibilities (Fox, 2009). In fact, Fox (2009) found that how motherhood impacts the life of women and the extent to which it exacerbates gender inequality in the household is strongly influenced by the context and social class of the new parents.

\section{Macro-level Influences}

As evidenced by increased attention to macro-level influences, these individual-level theories are only semi-successful in explaining the persistence of female responsibility for domestic chores. As stated by Fox, (2009) focusing on gender ideologies is insufficient, as it does not account for individual's material conditions or social resources. Doing gender is also not enough; it lacks context and places too much focus on the reproduction of gender rather than variation in behavior (Fox, 2009). National context is significant in defining the expectations for males and females, as well as how those roles might be carried out (Hook, 2006). Thus, while individual-level influences are important in explaining the division of labor, they are only part of the story. 
Macro-level influences offer a more holistic explanation for gender differentiation by "relying on various levels of analysis and postulating an interplay among technological market, political, cultural, interactional and personal factors in the distribution of labor" (Batalova and Cohen, 2002). The political perspective recognizes that male or female designated responsibilities, the result of social production, are fundamental to the functioning of society and influenced by economic organization (see Fox, 2009, p. 34). With gender firmly embedded in families' division of domestic work, how these responsibilities are negotiated reflects the power dynamics in the relationship and thus the social and economic resources available to each individual (Fox, 2009). Because access to and availability of such resources is often governed by cultural and structural factors, it follows that these relationships do not operate in isolation; they are affected by the society in which they are located (Ruppanner, 2010). What is difficult to ascertain, however, is the scope of influence of national-level factors versus individual-level factors and to account for crossnational variation in history, culture and language (see Knudsen and Waerness, 2008).

Many national-level factors have been considered in studies of the division of household responsibilities including prevailing gender attitudes, economic measures such as GDP or GNP, measures of female empowerment (GEM), welfare state regimes, composition of the labor force, policy and legislation, and demographic characteristics. As will be discussed, these influences are very interrelated and are at times indistinguishable from each other. Research has indicated that national trends in the division of labor are to some extent associated with the welfare state regime and gender ideology of the nation as a whole. That democratic nations tend to have higher levels of housework sharing than conservative societies is reflective of this relationship (Geist, 2005). The orientation of the state to gender and labor influences how families arrange work in different ways, one of which is the amount of value placed on male and female involvement in the labor force. It also influences the extent to which people's attitudes inform their behavior. In more egalitarian societies, for example, individual's gender ideologies and women's assets are often more influential in negotiating housework responsibility (Corrigall and Konrad, 2006; Fuwa, 2004). In conservative nations, a woman's egalitarian attitudes are less likely to result in higher sharing (Geist, 2005). In spite of these general trends, however, there remains much variation in how national gender attitudes influence behavior.

Egalitarianism has also been shown to have a positive relationship with GNP, per capita GNP, individualism, and women's empowerment (Apparala et al., 2003). In fact, studies have widely asserted the necessity of including a measurement of economic development, as it can trigger massive social and cultural changes that either support or undermine traditional divisions of labor. In-conjunction with gender empowerment (GEM) scores, egalitarian attitudes are also positively related to female resources, and the influence those assets have in determining housework arrangements (Apparala et al., 2003; Batalova and Cohen 2002; Fuwa, 2004). As GEM is reflective of women's power in the political and economic arenas, it is logical that authority in those spheres would transfer to the home. The effects of these macro-level factors are complex, however; female empowerment appears to not only have a greater effect when GDP is controlled for, but consistently exhibits a more pronounced effect on women (Knudsen and Waerness, 2008). That men appear to be more influenced by GDP is indicative of how different features of the national context yield varied micro-level outcomes (Knudsen and Waerness, 2008).

The allocation of household responsibilities is also the result of policies that regulate the integration of work/family domains and gender specialization (see Hook, 2006; LewinEpstien and Stier, 2006). As policy in many ways moderates the effect of female employment 
and men's work in the home, its significance has only grown with the rise in women working (Hook, 2006). There are essentially three types of policy that influence the division of labor and often encourage a more traditional arrangement: 1) Work regulations, 2) work/family policies, and 3) gender equality initiatives (Hook, 2006). The first might influence how domestic chores are divided by dictating the number of hours per week the working spouse is expected to devote to paid labor. The second type determines benefits offered such as childcare and parental leave. While these policies appear to support the participation of mothers in the labor force, they simultaneously reinforce gender specialization and the woman's role in the home during the critical transition to parenthood (Hook, 2006). As many societies provide mothers more childcare-related benefits than fathers, they support the female-caregiver/male-breadwinner designations and the "uninvolved fathering role" (Hook, 2006). In contrast, gender equality or neutral policy in many ways encourages the opposite, decreasing the appeal of specialized labor by focusing on an "individual system" as opposed to the traditionally bifurcated one. Clearly, different policies can have competing effects on the enactment of gender roles.

Of particular interest to this cross-national study is the gender dynamics and division of labor in Eastern Europe, which has had unique historical, cultural and economic influences in comparison to other countries included in this analysis. Under communism women were required to participate in the labor force yet domestic responsibilities remained traditionally divided (Ruppanner, 2010). Unlike other nations with high female employment, women in soviet Europe did not benefit from an "expansive welfare state." Even post-communism, these countries have large percentages of women in paid work and low levels of gender equality, which reports of frequent spousal conflict have been attributed to (Ruppanner, 2010). While these trends hold throughout the region, the situation is changing in some areas (Davis and Greenstein, 2004). For example, individuals in Russia, Estonia, Czech, and Hungary were more likely than Americans to claim that men perform at least half of household chores (Davis and Greenstein, 2004). Inter and intra-country differences remain, however, as exemplified by the Czech Republic which reports more egalitarian sharing than Hungary and Poland, but indicates female attitudes are liberalizing more rapidly than their male counterparts (Crompton, Brockmann, and Lyonette, 2005).

\section{Influence on Family Satisfaction}

As stated previously, there is little information in sociological literature linking attitudes and the division of labor to family satisfaction. The bulk of related gender studies focus on their relationship with other types of satisfaction, particularly marital. Research, however, asserts the interrelation of various types of satisfaction, as well as other measures of welfare, including well-being and happiness. Three arguments affirm their interchangeability and the utility of such measures in understanding family satisfaction. First of all, the literature indicates that satisfaction in different life domains contributes to overall life satisfaction. In this way satisfaction with work, home; marriage, and family are all positively associated with general satisfaction (Perrone, Webb, and Blalock, 2005). It is thus logical that two domains, marital satisfaction and family satisfaction, would be related. Secondly, the terms satisfaction and happiness, while slightly different concepts, are used essentially interchangeably in the literature and often treated as the same measure (Kamp Dush, Taylor, and Kroeger, 2008; Perrone et al., 2005). Finally, subjective well-being is a broader, but also interrelated term that encompasses domain satisfactions, life satisfaction, and happiness (see Andre $\beta$ and Brockel, 2007).

Because men and women experience marriage differently; variance in reported marital 
satisfaction and happiness appears to run along gendered lines. Perhaps one of the most important differences is that men report higher satisfaction with marriage in general (Kaufman and Taniguchi, 2006). Women seem to be more affected by the division of labor than are men and often report lower satisfaction with how housework is shared (Stevens, Kiger, and Riley, 2001). This relationship is not uniform, however, as it varies by context, female employment, and gender attitudes held by women (Apparala et al., 2003; Baxter and Western, 1998; Greenstein, 1996). Accordingly, homemaking and childcare in and of themselves do not "cause problems;" the social context and relationships in which they are entrenched can create issues such as power inequities, lack of opportunity, and exploitation (Fox, 2009, p. 86). Furthermore, it is not necessarily the actual allocation of housework or hours spent by women on domestic chores, but whether reality is consistent with the expectations (Greenstein, 1996).

An important consideration in a discussion of the relationship between attitudes, work sharing and satisfaction is perceived fairness. Fairness can be defined as equality, equity or need, and is deemed an important aspect of healthy 'intimate relationships' (see Nordenmark and Nyman, 2003). In fact, women's increased involvement in paid work seems to have increased the salience of perceived equity in marital happiness (Rogers and Amato, 2000). Despite the persistence of female responsibility for domestic duties, however, the vast majority of women believe their arrangement to be fair. That those with resources or more egalitarian attitudes are more likely to report perceived inequity speaks to the importance of socialization in the perception of faimess. It is unlikely that the actual division of labor in their households is less equitable than in those women claim are just; females with more traditional beliefs, or lacking in resources, are less likely to expect that men should share in domestic responsibility (see Nordenmark and Nyman, 2003; Rogers and Amato, 2000). While perception of inequity is in part determined by micro-level factors such as a woman's attitudes, macro-level factors also have an effect. Two of the most significant influences are general levels of gender inequality and the average amount of male/female sharing of domestic responsibility. As women use national norms to assess the fairness of their own divisions of labor, it is unsurprising that inequality is deemed less acceptable in more egalitarian places (Braun et al., 2008).

Despite apparently increased egalitarianism, several comparative studies have identified Eastern European countries as having low levels of happiness, well-being, contentment and general satisfaction (Abbott and Sapsford, 2006; Ball and Chernova, 2008; Bohnke, 2008; Hayo, 2004; Rehdanz and Maddison, 2005; Tsai, 2009). Some research points to the significance of these countries being in a 'transition stage,' contending that the move toward a market economy has been an "unhappy" one that has resulted in relatively low levels of wellbeing (Sanfey and Teksoz, 2005; Tsai, 2009). These researchers also argue that past satisfaction levels had been higher for pre-transition Eastern European countries, but they have not yet fully recovered from a mid-1990's drop caused by governmental and economic issues. Because : institutional settings can determine and limit opportunity, Eastern Europeans' life chances (and by extension happiness) seemingly depend on improving institutional, political and economic structures (Bohnke, 2008).

\section{Incongruence}

It follows that if egalitarian women tend to perceive more inequity in the division of labor, they would experience less marital satisfaction as a result of the incongruence between their attitudes and the housework arrangement. When possible, individuals choose family activities that confirm their gender identities (Kroska, 1997) but if economic or social factors 
prevent behavior from being consistent with attitudes, they may employ various coping mechanisms to assuage the dissonance. Frequently this entails adjusting attitudes to align them with reality (Diefenbach, 2002; Hook, 2006). One example of this might be a traditional woman who must work for economic reasons; because employment is more important than ideology she will likely revise the meaning of her involvement in domestic work (Stevens et al., 2001). Affect control theory and identity theory accordingly explain individuals cope by "changing the meanings attached to some element of the -work arrangement: their identity, their partner's identity, or their work activities." Hochschild (1989, p. 57) agreed, adding that individuals will do "extraordinary behind the scenes emotion work" to manage dissonance between attitudes and reality. She also explained that another way in which couples might manage inconsistency regarding the fulfillment of domestic duties is by developing "family myths" (Hochschild, 1989, p. 19). In this way a disagreement over the distribution of housework between an egalitarian wife and transitional husband might be managed by claiming they share the workload equally, regardless of whether they do or not.

Unsurprisingly, people whose activities are congruent with their feelings and values have been shown to experience greater life satisfaction (Perrone et al., 2005). Role congruence, the extent to which participation in a given life role correlates with the amount that role is valued, is in fact associated both directly and indirectly with well-being as inconsistency breeds conflict, depressing satisfaction (Perrone et al., 2005). Accordingly, congruence between a couple's gender role attitudes and the actual division of housework or childcare is related to marital satisfaction (see Apparala et al., 2003). We hypothesize that this relationship will hold true for family satisfaction as well. The aim of our study is thus to ascertain how family satisfaction is affected by instances of incongruence in ideology and behavior that result from a conglomerate of micro and macro-level influences.

Based on this review, we examine the association between gender role attitudes and the household division of labor, and family satisfaction as reported by married or cohabiting individuals living in 31 countries. In addition, we include measures of individual and couple characteristics, as well as country level measures. We estimate individual, couple, and country factors and their association with family satisfaction in regression models, as well as variation within and between countries based on multi-level models.

\section{METHOD}

\section{Sample}

Data for this study come from the 2002 International Social Survey Program (ISSP): Family and Changing Gender Roles III. These data are cross-national and examine family and gender roles in 31 countries: Austria, Australia, Bulgaria, Chile, Czech Republic, Denmark, Finland, Flanders (Belgium), France, Germany, Great Britain, Hungary, Ireland, Japan, Latvia, Mexico, Netherlands, New Zealand, Northern Ireland, Norway, Philippines, Poland, Portugal, Russia, Slovakian Republic, Spain, Sweden, Switzerland, Taiwan, and the United States (sample $n=41,332$ ). The ISSP also included data from Slovenia, Israel, Brazil, and Cyprus, but these countries were missing detailed household composition information and were excluded from this study. Because we are interested in the division of household labor and family satisfaction, we limit our sample to men and women living with a partner. Our analyses are based on a sample of 25,750 married or cohabiting adults.

In addition to measures in the ISSP Family and Changing Gender Roles. Survey, we also 
examine country level measures. Various demographic indicators and family policy measures were obtained from the World Population Data Sheet (Population Reference Bureau, 2012) and the Woman Stats Project website (Woman Stats Project, 2012). These country level measures were matched by country to the individual level data provided in the Family and Changing Gender Roles Survey, 2002.

\section{Model Specifications}

Our dependent variable is a scale measuring family life satisfaction (see Table 1). Survey subjects were asked, "All things considered, how satisfied are you with your family life?" Responses are based on a scale from (1) completely dissatisfied to (7) completely satisfied.

Gender role attitudes and household labor are measured by three variables-division of household labor, joint decision-making, and attitudes about the role of men in household work. The division of household work is measured by responses to the question, "In your household, who does the following things?" Separate questions were then asked about individual household tasks. The responses to the following tasks were combined to form a single scale by averaging the responses. The tasks included: laundry, caring for sick family members, shopping for groceries, household cleaning, and preparing meals. The responses to each question regarding who does each task are based on the following scale: (1) always the respondent, (2) usually the respondent, (3) about equal or both together (or a third person), (4) usually my spouse/partner, (5) always my spouse/partner.

Joint decision-making is measured by whether or not respondents indicated they make decisions together. Responses to two questions: "Who has the final say in choosing shared weekend activities?" and "Who has the final say in buying major things for the home?" were coded 1 if the respondent indicated that they decide together, and coded 0 otherwise. These dichotomies were then summed so that the final joint decision measure indicates how many of the two decisions are made jointly-zero, one, or two.

Attitudes regarding the role of men in household work are measured by averaging agreement to the following two statements: "Men ought to do a larger share of household work than they do now" and "Men ought to do a larger share of childcare than they do now." Responses to these statements are based on an agreement scale from (1) strongly agree to (5) strongly disagree. Other measures of gender ideology and time spent on household chores were also examined in preliminary analyses, but were not associated with family satisfaction and were excluded from further analyses.

Incongruence between ideology and behavior was measured by creating a cross categorization between couple employment arrangements, and respondent attitudes towards gender roles. Respondents were asked to indicate their agreement (strongly agree to strongly disagree) with the statement, "A man's job is to earn money; a woman's job is to look after the home and family." Responses were collapsed into three categories (I) strongly agree or agree, (2) neither agree nor disagree, and (3) strongly disagree or disagree. This measure was then cross categorized with a dichotomous measure indicating whether or not the respondent is. in a traditional partnership (man employed, woman homemaker). If the respondent is in a traditional partnership and the respondent agreed with the gender role statement, he or she was coded as (1) congruent. If they were in a traditional partnership and disagreed with the statement, he or she was coded as (3) incongruent. The opposite was coded for those in non-traditional partnerships ("disagree" coded as congruent (1), "agree" coded as incongruent (3)). Respondents reporting that they neither agreed nor disagreed with. 
the gender role statement were coded as (2) neither congruent nor incongruent, irrespective of their employment arrangement.

Respondent characteristics include measures of gender, age, and religion. Gender is a dichotomous measure coded 1 if the respondent was male and 0 if female. Age is measured in years and ranges from 15 to 92 . Based on preliminary analyses, Catholic or Protestant religious affiliation were similarly associated with family satisfaction; thus, religious affiliation is a dichotomy coded 1 if Catholic or Protestant (mainstream Christian religion) and 0 otherwise. Religious attendance is based on a scale from $1=$ several times a week or daily attendance, to $8=n e v e r$ attend religious services. Preliminary analyses also included measures of education, but no significant association between education and family satisfaction was found, so education was excluded.

Couple characteristics include a measure of employment and household type. Following preliminary analyses examining full-time work, part-time work, unemployment, and full time homemaking for respondents and partners, traditional family patterns in which the man was employed and the woman was a homemaker were found to be associated with family satisfaction. This measure is a dichotomy coded 1 if the male in the partnership is identified as working, and the female is identified as a full-time homemaker. All other employment/family arrangements are coded as 0 . In addition, various family arrangements in terms of the number of adults and children in the home were also examined in relationship to family satisfaction in preliminary analyses. Living only with a partner, or living with a partner and children were found to be similarly associated with family satisfaction. This measure is a dichotomy coded 1 if the family is nuclear (couple with or without children), and 0 otherwise (extended family).

Country level measures were obtained for levels of development, demographic indicators, and measures of family laws or policies. Following initial analyses, country level measures of development were combined to create a factored scale from low to high. The combined measure includes male and female life expectancy and the human development index (HDI). This final factor ranges from low life expectancy and development to high life expectancy and development. In initial analyses, measures of gender empowerment (GEM) were not significantly associated with family satisfaction and were not included in further analyses.

A measure of inequity in family law was obtained from the Women Stats Project. This scale (2007 data), developed by McDermott (University of California-Santa Barbara), seeks to capture how inequitably family law is conceptualized according to gender (Woman Stats Project, 2012). Intercoder reliability for this coding round was 85 percent. This variable is based on a scale from 0 to 4 , where 0 indicates a country where legal marriage is age 18 , marital rape and polygyny are illegal, and abortion and divorce are legal. A value of 4 indicates a country that provides none of these protections.

In addition, regional effects were also explored in initial analyses. In particular, several former eastern bloc countries were found to have significantly lower levels of family satisfaction relative to other countries. A dichotomous measure indicating these countries (Czech Republic, Bulgaria, Russia, Latvia, and Slovak Republic) is included in analyses. Although East Germany, Hungary, and Poland are also former eastern bloc countries, mean levels of family satisfaction in these countries were significantly different from the other five countries and thus, these countries were not included in our measure of eastern bloc countries. 


\section{Estimation Procedure}

Initial analyses were run using OLS regression to determine significant associations with family satisfaction. In addition, interactions were included between gender and the gender role and household labor measures. Following preliminary analyses, multiple imputation was then used to estimate values for missing data in Stata. The idea of multiple imputation is to create multiple imputed data sets for a data set with missing values. The analysis of a statistical model is then done on each of the multiple data sets. The multiple analyses are then combined to yield a set of results (Royston, 2004). In general, multiple imputation techniques require that missing observations are missing at random. All independent measures in our analyses were missing at most three percent of the cases, with the exception of religious attendance (10 percent missing), and traditional roles (man works, woman homemaker- 6 percent missing). Thus, coefficients for these two variables require more caution in interpretation.

Our results are presented as follows: first we present descriptive statistics for family satisfaction and predictors across the sample of individuals from the 31 countries. Next, we present mean differences in gender role attitudes and household labor, as well as couple and respondent characteristics by gender, and then by whether or not the couple report traditional roles-man working, woman homemaker. We then present the coefficients for the regression models based on the multiple imputation data sets. In the regression results, the association between various factors and family satisfaction are presented in five expanding models: (1) gender role attitudes and household labor measures; (2) gender role attitudes and division of household labor, and the incongruence measure, (3) respondent and couple characteristics added; (4) country level measures added, and finally (5) gender interactions are included. Following the regression models reported in Table 4, results from the multilevel analyses are presented examining within and between country variation in family satisfaction.

\section{RESULTS}

Descriptive Statistics are provided in Table 1. Respondents reported high satisfaction on average with the mean score across all respondents being 5.7. In terms of gender roles and household work, most respondents reported on average doing more household labor relative to their spouse or partner. Household labor includes laundry, care for sick family members, shopping for groceries, cleaning, and cooking. On average, respondents indicated that they made one of the two major decisions together. Expectations for male involvement in household work and childcare show that on average respondents agreed more than disagreed that men ought to be doing more.

About 46 percent of respondents were men, and the average age was 47 years. Sixty-five percent said they were affiliated with either a Protestant or Catholic religion and on average, religious attendance was less than monthly. Couple characteristics indicate that 36 percent of the respondents reported being in a traditional relationship-man employed and woman unemployed. Seventy percent of those surveyed were in nuclear families-a couple with or without children.

Fifteen percent of the countries surveyed were identified as eastern bloc as measured in our analyses. The mean score across countries for inequity in family law was .62 - where 0 indicates multiple legal protections (legal marriage age 18, marital rape illegal, polygyny illegal, abortion and divorce legal). A score of 1 indicates that the legal age of marriage is at 
Table 1

Descriptive Statistics for Family Satisfaction, Gender Roles and Household Labor, Respondent and Couple Characteristics, and Country Level Measures $(\mathrm{N}=\mathbf{2 5}, \mathbf{7 5 0})$

\begin{tabular}{|c|c|c|c|c|}
\hline Variables & $M$ & $S D$ & Range & $\alpha$ \\
\hline Dependent variable & & & & \\
\hline Satisfaction with family life & 5.67 & .99 & $1-7$ & \\
\hline \multicolumn{5}{|l|}{ Gender Role Attitudes and Household Labor } \\
\hline Division of household labor ${ }^{a}$ & 2.77 & 1.13 & $1-5$ & .91 \\
\hline Joint decision-making ${ }^{b}$ & 1.13 & .86 & $0-2$ & .70 \\
\hline Men ought to do larger share ${ }^{c}$ Incongruence ${ }^{d}$ & 2.33 & .89 & $1-5$ & .80 \\
\hline Respondent Characteristics & 1.94 & .91 & $1-3$ & \\
\hline Gender $^{\circ}$ & .46 & .50 & $0-1$ & \\
\hline Age & 47.04 & 14.57 & $15=92$ & \\
\hline Mainstream religion $^{i}$ & .65 & .48 & $0-1$ & \\
\hline Religious attendance ${ }^{\mathrm{B}}$ & 5.61 & 2.40 & $1-8$ & \\
\hline Couple Characteristics & & & & \\
\hline Traditional roles $^{\mathrm{h}}$ & .36 & .48 & $0-1$ & \\
\hline Nuclear family & .70 & .46 & $0-1$ & \\
\hline \multicolumn{5}{|l|}{ Country Level Factors } \\
\hline Eastern bloc countries & .15 & .35 & $0-1$ & $\therefore \therefore$ \\
\hline Development factor & .00 & 1.00 & $-2.65-1.13$ & \\
\hline Inequity in family law ${ }^{k}$ & .62 & .66 & $0-4$ & \\
\hline
\end{tabular}

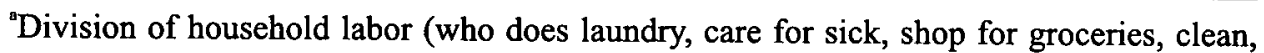
cook): 1=always respondent, 5=always spouse/partner. 'Joint decision-making (choose weekend activities, major purchases for home): $0=$ no decisions together, $1=$ one decision together, $2=$ both decisions together. Men ought to do larger share (household work and childcare): I=strongly agree, 5=strongly disagree. 'Incongruence (between attitude and behavior): $1=$ congruent, $3=$ incongruent. ' Gender: $0=$ female, $1=$ male. 'Mainstream religion: $0=$ o, $1=$ yes. ${ }^{\mathrm{B}}$ Religious attendance: $1=$ several times a week or daily, $8=$ never. ${ }^{\mathrm{h}}$ Traditional roles: $0=$ non-traditional, $1=$ traditional (husband employed, wife homemaker). 'Nuclear family: $0=$ extended family, $1=$ couple with or without children. ${ }^{j}$ Eastern bloc countries: 0=non-Eastern bloc, 1=Czech Republic, Bulgaria, Russia, Latvia, Slovak Republic. "Inequity in family law: $0=$ legal marriage age 18; marital rape, polygyny illegal; abortion and divorce legal, $2=$ moderate protections, $4=$ no protections.

Source: International Social Survey Program: Family and Changing Gender Roles III, 2002

least 16, marital rape and polygyny are illegal, abortion and divorce are legal but laws tend to favor men in property rights (including after divorce), and abortion may not be available on demand. No countries rated a 3 or 4 on the inequity scale in our sample, and only about 10 percent of the countries had a score of 2.

Mean gender differences in family satisfaction and various predictors are presented in Table 2. Men report somewhat higher mean levels of family satisfaction relative to women, and they also indicate that their spouse or partner does more of the housework on average, relative to themselves. There was no gender difference in joint decision-making, but men were also somewhat more likely to disagree on average that they ought to do a larger share of housework or childcare relative to women. Incongruence between work/family relationships and attitudes was slightly higher among male respondents than among females. 
Demographic differences indicate that women are about four years younger than their partners on average, and slightly more likely to be affiliated with a Protestant or Catholic religion relative to their partner. Women also report somewhat higher religious attendance than men. These gender differences suggest that on average, women do most of the household chores, but this arrangement is more satisfying in terms of family life for men, than for women.

Table 2

Mean Gender Differences in Family Satisfaction, Gender Roles and Household Labor, Respondent and Couple Characteristics

\begin{tabular}{lcc}
\hline Characteristic & $\begin{array}{c}\text { Women } \\
n=13,945\end{array}$ & $\begin{array}{c}\text { Men } \\
n=11,805\end{array}$ \\
\hline Family satisfaction & 5.60 & $5.75^{* * *}$ \\
Division of household labor & 1.94 & $3.74^{* * *}$ \\
Joint decision-making & 1.13 & 1.14 \\
Men ought to do larger share & 2.23 & $2.44^{* * *}$ \\
Incongruence & 1.91 & $1.96^{* * *}$ \\
Age & 45.09 & $49.34^{* * *}$ \\
Mainstream religion & 0.66 & $0.63^{* * *}$ \\
Religious attendance & 5.42 & $5.83^{* * *}$ \\
Traditional roles & 0.37 & $0.34^{* * *}$ \\
Nuclear family & 0.70 & 0.70 \\
\hline
\end{tabular}

Source: International Social Survey Program: Family and Changing Gender Roles III, 2002

Note: ${ }^{* * *} \mathrm{p}<.001$ based on two mean t-tests (two-tailed)

These same mean gender differences are then broken down by whether or not the respondent reported being in a traditional relationship (man breadwinner, woman homemaker). Table 3 shows that both men and women in traditional relationships reported slightly higher family satisfaction on average, compared to respondents in non-traditional relationships. Women in non-traditional relationships report that their partner does more housework than do women in traditional relationships. Among men, non-traditional men report that they do more housework on average, and are also slightly more likely to report making joint-decisions with their partner, relative to men in traditional relationships. Both men and women in nontraditional relationships are somewhat more likely to agree that men ought to do a larger share of housework and childcare, relative to those in traditional relationships. Incongruence between work/family patterns and attitudes was more likely among traditional men and women, relative to those in non-traditional relationships.

Men and women in traditional relationships are also much younger on average, relative to those in non-traditional relationships; this may reflect differences in age of union formation. Non-traditional women are somewhat less likely to be affiliated with a Protestant or Catholic religion, and both men and women in non-traditional relationships report lower religious attendance relative to those in traditional relationships. Men in non-traditional, compared to traditional relationships were also somewhat more likely on average to be in a nuclear family. These general patterns suggest that across these countries, men and women in traditional economic relationships follow traditional gender divisions in household labor, and their attitudes and family satisfaction are supportive of this division of labor, although they also identified as having greater incongruence between attitudes and behaviors.

Moving to the multivariate analyses, Table 4 presents multiple regression coefficients for the 
Table 3

\section{Mean Differences by Men and Women in Traditional, versus Nontraditional Relationships}

\begin{tabular}{lcccc}
\hline & \multicolumn{2}{c}{ Women } & \multicolumn{2}{c}{ Men } \\
\hline Characteristic & Traditional & Nontraditional & Traditional & Nontraditional \\
& $n=4,809$ & $n=8,264$ & $n=3,779$ & $n=7,259$. \\
\hline Family satisfaction & 5.68 & $5.56^{* * *}$ & 5.82 & $5.72^{* * *}$ \\
Division of household labor & 1.79 & $2.03^{* * *}$ & 3.91 & $3.66^{* * *}$ \\
Joint decision-making & 1.11 & 1.14 & 1.08 & $1.16^{* * *}$ \\
Men ought to do larger share & 2.29 & $2.19^{* * *}$ & 2.48 & $2.41^{* * *}$ \\
Incongruence & 2.26 & $1.71^{* * *}$ & 2.10 & $1.89^{* * *}$ \\
Age & 41.19 & $47.55^{* * *}$ & 44.08 & $52.26^{* * *}$ \\
Mainstream religion & 0.69 & $0.67^{* *}$ & 0.63 & 0.64 \\
Religious attendance & 5.30 & $5.42^{* *}$ & 5.72 & $5.83^{*}$ \\
Nuclear family & 0.69 & 0.69 & 0.67 & $0.71^{* * *}$ \\
\hline
\end{tabular}

Source: International Social Survey Program: Family and Changing Gender Roles III, 2002

Note: ${ }^{*} p<.05,{ }^{* *} p<.01$, and ${ }^{* * *} p<.001$ mean differences between traditional and nontraditional roles based on two mean t-tests (two-tailed)

five models predicting family satisfaction. Coefficients in model 1 indicate that having a spouse or partner do the majority of household labor is associated with higher family satisfaction. This relationship only strengthens as other factors are included in the analyses. The more major decisions are made jointly, the higher family satisfaction, and this relationship remains relatively stable across the models. Attitudes about.the role of men in household labor and childcare indicate that the more respondents disagree that men ought to do more, the higher their family satisfaction. Coefficients in the second model show that if the work/family behaviors are compatible with the respondent's expectations, family satisfaction is somewhat higher. This relationship, however, reaches non-significance once the measure for eastern bloc countries is included in the analyses (model 4). Additional analyses indicate that incongruence is higher among respondents in eastern bloc countries relative those not living in these countries.

The addition of respondent and couple characteristics is provided in model 3. Respondent characteristics indicate that family satisfaction is associated with Protestant or Catholic affiliation and with religious attendance. Respondents in traditional roles (breadwinner male, homemaker female) report higher family satisfaction, relative to those in nontraditional roles, as do those in nuclear family arrangements compared to respondents living with extended family. Older age is associated with a decrease in family satisfaction, and there is no gender difference in satisfaction. Higher national development is associated with higher family satisfaction, as shown in model 4. Surprisingly, somewhat less stringent family law protections are also associated with higher family satisfaction. In addition, respondents living in the eastern bloc reported the lowest levels of family satisfaction compared to those living in other countries, even after controlling for other individual factors. Interactions, presented in model 5, demonstrate that men report higher family satisfaction the more they are involved in household labor. In addition, men indicate higher family satisfaction the more they agree they ought to be more involved in household work and childcare. Thus, for men in particular, increased household and family participation is associated with greater family satisfaction in the multivariate analyses. 
Table 4

\section{Summary of Hierarchical Regression Analysis of Factors}

Predicting Family Satisfaction (N=25,750)

\begin{tabular}{|c|c|c|c|c|c|}
\hline Characteristics & $\begin{array}{c}\text { Model } 1 \\
\text { B }\end{array}$ & $\begin{array}{c}\text { Model } 2 \\
\text { B }\end{array}$ & $\begin{array}{c}\text { Model } 3 \\
\text { B }\end{array}$ & $\begin{array}{c}\text { Model } 4 \\
\text { B }\end{array}$ & $\begin{array}{c}\text { Model } 5 \\
\text { B }\end{array}$ \\
\hline \multicolumn{6}{|l|}{$\begin{array}{l}\text { Gender Role Attitudes and } \\
\text { Household Labor }\end{array}$} \\
\hline Division of household labor & $.077 * * *$ & $.077^{* * *}$ & $.083 * * *$ & $.086^{* * *}$ & $.157^{* * *}$ \\
\hline Joint decision-making & $.174 * * *$ & $.174^{* * *}$ & $.178^{* * *}$ & $.180^{* * *}$ & $.174^{* * *}$ \\
\hline Men ought to do larger share & $.031 * * *$ & $.031 * * *$ & $.024^{* * *}$ & $.024 * * *$ & $.091 * * *$ \\
\hline Incongruence & & $-.015^{*}$ & $-.024 * *$ & -.011 & -.014 \\
\hline \multicolumn{6}{|l|}{ Respondent and Couple } \\
\hline \multicolumn{6}{|l|}{ Characteristics } \\
\hline Male & & & .027 & .016 & $.716^{* * *}$ \\
\hline Age & & & $-.003^{* * *}$ & $-.003 * * *$ & $-.003 * * *$ \\
\hline Mainstream religion & & & $.120 * * *$ & $.065^{* * *}$ & $.068 * * *$ \\
\hline Religious attendance & & & $-.037 * * *$ & $-.031 * * *$ & $-.031 * * *$ \\
\hline Traditional roles & & & $.100^{* * *}$ & $.054 * * *$ & $.071^{* * *}$ \\
\hline Nuclear family & & & $.096 * * *$ & $.090 * * *$ & $.083^{* * *}$ \\
\hline Country Variables & & & & & $\cdot$ \\
\hline Development factor & & & & $.044 * * *$ & $.047^{* * *}$ \\
\hline Family law inequality & & & & $.102 * * *$ & $.102 * * *$ \\
\hline Eastern bloc countries & & & & $-.330 * * *$ & $-.307 * * *$ \\
\hline \multicolumn{6}{|l|}{ Interactions } \\
\hline Male $\mathrm{x}$ Men ought to larger share & & & & $-.145^{* * *}$ & \\
\hline Male x Division of household labol & & & & $-.139 * * *$ & \\
\hline Male x Incongruence & & & & & .017 \\
\hline $\mathbf{R}^{\mathbf{2}}$ & .03 & .03 & .05 & .07 & .08 \\
\hline$F$ for change in $\mathrm{R}$ & & 0.00 & $85.91 * * *$ & $174.35 * * *$ & $65.18^{* * *}$ \\
\hline
\end{tabular}

Note: $* \mathrm{p}<.05 \quad * * \mathrm{p}<.01 * * * \mathrm{p}<.001$

Source: International Social Survey Program: Family and Changing Gender Roles III, 2002

Multi-level analyses were next performed to examine variation in family satisfaction within and between countries. Model 1 indicates that most of the variation in family satisfaction is within countries, with only about 4 percent of the variation being between countries. Model 2 includes the individual level measures and allows for a random constant (different intercepts). Model 3 includes the individual level measures, as well as the country level measures. The between country percentage drops to $1.6 \%$ with the inclusion of the country level variables. Thus, what little variation in family satisfaction there is between countries is explained in part by our country level indicators. Model 4 allows for random effects (different slopes). The inclusion of random effects significantly improves the fit of the model, indicating that the effect of individual and country measures on family satisfaction varies across countries.

\section{DISCUSSION}

Although cross-nationally women have increased their participation in paid labor, they continue to do the majority of household work, even in nontraditional families (Diefenbach, 2002; Doucet, 2006; Lewin-Epstein and Stier; 2006). Mean differences between men and women across the thirty-one countries we analyzed show that men are happier with family 
Table 5

\section{Multi-level Models of Across and Within Country Variation} in Satisfaction with Family Life $(\mathbf{N}=\mathbf{2 5 , 7 5 0})$

\begin{tabular}{lcccc}
\hline $\begin{array}{l}\text { Variation in Satisfaction } \\
\text { with Family Life }\end{array}$ & $\begin{array}{c}\text { Model 1 } \\
\text { (random } \\
\text { constant) }\end{array}$ & $\begin{array}{c}\text { Model 2 } \\
\text { (individual } \\
\text { measures } \\
\text { and random } \\
\text { constant) }\end{array}$ & $\begin{array}{c}\text { Model 3 } \\
\text { (individual } \\
\text { level, country } \\
\text { level, and } \\
\text { random } \\
\text { constant) }\end{array}$ & $\begin{array}{c}\text { Model } \\
\text { (individual } \\
\text { level, random } \\
\text { effects) }\end{array}$ \\
\hline $\begin{array}{l}\text { Between country (\% of total) } \\
\text { Within country }\end{array}$ & $.0417(4.1 \%)$ & $.0320(3.3 \%)$ & $.0150(1.6 \%)$ & \\
2Log Likelihood & .9819 & .9378 & .9378 & .9130 \\
Degrees of freedom & 235783.28 & 215973.32 & 215961.6 & $214536.26^{* * *}$ \\
\hline
\end{tabular}

Source: International Social Survey Program: Family and Changing Gender Roles III, 2002

life than are women, in part because women do more housework. In particular, men in traditional relationships (man breadwinner, woman homemaker) are the most satisfied with family life and the least likely to agree that men should be more involved. At the other end of the spectrum, nontraditional women are the least satisfied with family life, and the most likely to agree that men should do more at home. This lends support to the time availability argument, which posits that it is 'fair' for the partner most engaged in market labor to spend the least time on household work (Braun et al., 2008; Fox, 2009). From this perspective, nontraditional women engaged in paid labor would view as unsatisfactory their greater involvement in domestic labor relative to their partner, whereas traditional women would not. Alternatively, the association between family roles and satisfaction could also be in part a selection effect; women least interested in or satisfied with family life may select into nontraditional partnerships.

Our multivariate analyses, however, paint a somewhat different portrait of family satisfaction. Gender differences in family satisfaction do not emerge, but partner involvement in housework and joint decision-making are predictive of greater satisfaction. In addition, those in traditional roles (man breadwinner, women homemaker) report higher satisfaction, as do those with greater congruence between attitudes and behaviors. Thus, as noted by Fox (2009), homemaking and childcare in and of themselves do not "cause problems" or lower family satisfaction, instead the social context in which they are embedded can create power inequities, lack of opportunity, and exploitation. Family satisfaction depends, even among traditional divisions of labor, on both partners contributing to decision-making and housework. In particular, we find that satisfaction is higher among men that report greater involvement in childcare and household chores, and that agreed they ought to be more involved. Our findings provide support for the conclusion that spouses are more satisfied when not solely responsible for a given household task (Grote et al., 1996).

Although those in traditional partnerships report higher family satisfaction, nontraditional partners experience less incongruence between their attitudes regarding the division of labor in the home and actual behavior. Traditional women (homemakers) are identified with the highest incongruence, and nontraditional women the lowest. It is unclear why women in 
traditional roles experience greater dissonance between their attitudes and behavior. It may be because their attitudes towards gender roles are more liberal than their behavior, or because they feel conflict between the homemaker role and economic strain on the family. Although we find congruence between attitudes about family roles and behavior to be predictive of satisfaction with family life, this effect became non-significant once country measures were included in our models. Thus the association between congruence and satisfaction is explained by the context.

Individuals in former eastern bloc countries experienced lower satisfaction with family life and greater incongruence, relative to those in other countries. Even after controlling for individual characteristics, the economic and social transitions in former eastern bloc countries continued to negatively influence family satisfaction. Under communism, high female labor participation was required, but the division of household labor remained traditional (Panayotova and Brayfield, 1997). Ruppanner (2010) suggests that because postcommunist countries have high levels of full-time female labor force participation, but low levels of gender equality, higher levels of conflict over the division of housework have resulted. Such household conflict is one potential explanation for the low levels of family satisfaction among former eastern bloc countries. Another potential source of conflict in these households is that the gender role attitudes of women are liberalizing much faster than those of men (Crompton, et al., 2005). Both high female labor force participation coupled with low gender equality and women's gender role attitudes changing faster than men's could lead to greater incongruence for women in terms of attitudes and behaviors in the context of post-communism.

Context also matters in that family satisfaction is higher in countries with higher levels of socioeconomic development. It may be that family satisfaction is higher when couples can divide family responsibilities between the homemaker and breadwinner roles in a context of economic development, rather than both partners having to juggle work and family roles under a context of economic strain. Development may also allow for greater congruence between attitudes and behaviors in that one partner (generally the man) can support the family on one income and allow the other partner to focus on home life without economic strain in traditional families; or in the case of nontraditional couples, economic development may enhance congruence between liberal attitudes about work and family roles and actual opportunities. It should be noted, however, that the majority of countries included in this survey were developed countries or countries with developing or emerging economies. The least developed countries were not part of the survey. Further research is needed to determine if similar family patterns emerge in a less developed context.

Further, family satisfaction is also associated with less stringent family equity laws. The biggest difference between the family equity laws of the surveyed countries is the legal age of marriage. Legal age of marriage ranged from 18 years to 16 years. Countries ranked higher on the family equity measure reported a higher percentage of girls marrying at younger ages. Thus, it may be that this indicator reflects age at marriage more than differences in other family laws. Further study is needed to sort out these effects at the country level, in particular given that younger respondents reported greater satisfaction with family life relative to older respondents.

Overall, we find greater variation in family satisfaction within countries than between countries. The highest family satisfaction appears to be among couples that follow traditional roles (man breadwinner, woman homemaker), but where both partners are involved in household chores and family life, and where there is greater congruence between 
attitudes and behaviors regarding family roles. This conclusion, coupled with the finding that men more involved in household labor report higher satisfaction, concurs with Khawaja and Habib (2007), who found that traditional women whose husbands helped with housework were the happiest. These patterns are predictive of family satisfaction within a context of development and where policies generally support women's rights. The variation between countries is explained in large part by our measures of individual and country characteristics, and analyses indicate that the effect of these factors on family satisfaction varies by country.

A primary data limitation in our analysis is that we do not account for social class or labor market position. The data available in the survey are relatively limited in terms of occupation, and measure primarily hours worked, full-time versus part-time status, and whether employment is in the private or public sector. Cross-national occupational comparisons are difficult given the data limitations. Initially, we did include education of respondent and spouse in our models of family satisfaction as an indicator of social class. However, because education level was not predictive of family satisfaction in any of our models, we excluded it from final analyses for reasons of parsimony. Future research, however, should consider how social class and market position interact with ideology and household work availability:

Despite these data limitations, our findings underscore the importance of the household division of labor and the national context to family satisfaction. At least in relatively more developed countries, the involvement of men in family life is associated with greater family satisfaction. Development and family policies that encourage and support father involvement in household responsibilities are likely to increase family satisfaction, even among couples in more traditional family roles; and this relationship appears to be consistent cross-nationally.

\section{REFERENCES}

Abbott, P., and R. Sapsford. (2006). Life-satisfaction in post-Soviet Russia and Ukraine. Journal of Happiness Studies, 7,251-287.

Allen, S.M., and P.S. Webster. (2001). When wives get sick: Gender role attitudes, marital happiness, and husband's contribution to household labor. Gender and Saciety, 15, 898-916.

Andre $\beta ; H . J$. and M. Brockel. (2007). Income and life satisfaction after marital disruption in Germany. Journal of Marriage and Family, 69, 500-512.

Apparala, M.L., A. Reifman, and J. Munsch. (2003). Cross-national comparison of attitudes toward fathers' and mothers' participation in household tasks and childcare. Sèx Roles, 48, 189-203.

Ball, R., and K. Chernova. (2008). Absolute income, relative income, and happiness. Social Indicators Research, 88, 497-529.

Batalova, J.A., and P.N. Cohen. (2002). Premarital cohabitation and housework: Couples in crossnational perspective. Journal of Marriage and Family, 64, 743-755.

Baxter, J. (2002). Patterns of change and stability in the gender division of household labour in Australia, 1986-1997. Journal of Sociology, 38, 399-426.

Baxter, J., and M. Western. (1998). Satisfaction with housework: Examining the paradox. Sociology, $32,101-120$.

Bianchi, S.M., M.A. Milkie, J.P. Robinson, and L.C. Sayer. (2000). "Is anyone doing the housework?" Trends in the gender division of household labor. Social Forces, 79, 191-228: 
Bohnke, P. (2008). Does society matter? Life satisfaction in the enlarged Europe. Social Indicators Research, 87, 189-210.

Braun, M., N. Lewin-Epstein, H. Stier, and M.K. Baumgartner. (2008). Perceived equity in the gendered division of household labor. Journal of Marriage and Family, 70, 1145-1156.

Chen, F. (2005). Employment transitions and the household division of labor in China. Social Forces, $84,831-851$.

Coltrane, S. (2000). Research on household labor: Modeling and measuring the social embeddedness of routine family work. Journal of Marriage and the Family, 62, 1208-1233.

Crompton, R., M. Brockmann, and C. Lyonette. (2005). Attitudes, women's employment and the domestic division of labour: A cross-national analysis in two waves. Work, Employment and Society, $19,213-233$.

Davis, S.N. and T.N. Greenstein. (2004). Cross-national variations in the division of household labor. Journal of Marriage and Family, Special Issue: International Perspectives on Families and Social Change, 66, 1260-1271.

Diefenbach, H. (2002). Gender ideologies, relative resources, and the division of housework in intimate relationships: A test of Hyman Rodman's theory of resources in cultural context. International Journal of Comparative Sociology, 43, 45-64.

Doucet, A. (2006). Do Men Mother? Toronto: University of Toronto Press.

Fernandez, C. and A. Sevilla-Sanz. (2006). Social norms and household time allocation. Department of Economics Discussion Paper Series.

Fox, B. (2009). When Couples Become Parents: The Creation of Gender in the Transition to Parenthood. Toronto: University of Toronto Press.

Geist, C. (2005). The welfare state and the home: Regime differences in the domestic division of labour. European Sociological Review, 21, 23-41.

Greenstein, T. N. (1996). Gender ideology and perceptions of the faimess of the division of household labor: Effects on marital quality. Social Forces, 74, 1029-1042.

Habib, R. R., I.A. Nuwayhid and J.S. Yeretzian. (2006). Paid work and domestic labor in disadvantaged communities on the outskirts of Beirut, Lebanon. Sex Roles, 55, 321-329.

Hayo, B. (2004). Happiness in Eastern Europe. Philipps-University Marburg añd ZEI, University of Bonn.

Hochschild, A. R. (1989). The Second Shift. New York: Avon.

Hook, J.L. (2006). Care in context: Men's unpaid.work in 20 countries, 1965-2003. American Sociological Review, 71, 639-660.

Iversen, T. and F. Rosenbluth . (2003). The political economy of gender: Explaining cross-national variation in household bargaining, divorce and the gender voting gap. Paper presented at the Annual Meetings of the American Political Science Association in Philadelphia Pennsylvania.

Kamp Dush, C.M., M.G. Taylor and R.A. Kroeger. (2008). Marital happiness and psychological wellbeing across the life course. Family Relations, 57, 211-226.

Kaufman, G. and H. Taniguchi. (2006). Gender and marital happiness in later life. Journal of Family Issues 27, 735 .

Knuidsen, K. and K. Waerness. (2008). National context and spouses' housework in 34 countries. European Sociological Review, 24, $97-113$.

Kroska, A. (1997). The division of labor in the home: A review and reconceptualization. Social Psychology Quarterly, 60,304-322.

Khawaja, M. and R.R. Habib: (2007). Husband's involvement in housework and women's psychosocial health: Findings from a population-based study in Lebanon. American Journal of Public Health, 97, 860-866. 
Lewin-Epstein,N. and H. Stier. (2006). The division of household labor in Germany and Israel. Journal of Marriage and Family 86, 1147.

Nordenmark, M. and C. Nyman. (2003). Fair or unfair? Perceived fairness of household division of labour and gender equality among women and men: The Swedish case. The European Journal of Women's Studies, 10, 181.

Panayotova, E. and A. Brayfield. (1997). National context and gender ideology: Attitudes towards women's employment in Hungary and the United States. Gender and Society, 11, 627-655.

Perrone, K.M, K.L. Webb and R.H. Blalock. (2005). The effects of role congruence and role conflict on work, marital and life satisfaction. Journal of Career Development, $31,225$.

Population Reference Bureau. (retrieved 2012). 2008 World Population Data Sheet. Available at http://www.prb.org/Publications/Datasheets/2008/2008wpds.aspx

Rehdanz, K. and D. Maddison. (2005). Analysis: Climate and happiness. Ecological Economics, 52, 111-125.

Rogers, S.T. and P.R. Amato. (2000). Have changes in gender relations affected marital quality? Social Forces, 79, 731-753.

Ruppanner, L. (2010). Conflict and housework: Does country context matter? European Sociological Review, 26, 557-570.

Sanchez, L. and E. Thomson. (1997). Becoming mothers and fathers: Parenthood, gender, and the division of labor. Gender and Society, 11, 747-772.

Sanfey, P. and U. Teksoz. (2005). Does transition make you happy? European Bank for Reconstruction and Development. Working Paper No. 91.

Stevens, D., G. Kiger and P.J. Riley. (2001). Working hard and hardly working: Domestic labor and marital satisfaction among dual-earner couples. Journal of Marriage and Family, 63, 514-526.

Tsai, M. C. (2009).: Market openness, transition economies and subjective well-being. Journal of Happiness Studies, 10,523-539.

Woman Stats Project. (retrieved 2012). Available at http://www.womanstats.org/ ; codebook http://www.womanstats.org/Codebook7.30.07.htm\#MULTIVAR 
Copyright of Journal of Comparative Family Studies is the property of Journal of Comparative Family Studies and its content may not be copied or emailed to multiple sites or posted to a listserv without the copyright holder's express written permission. However, users may print, download, or email articles for individual use. 